\title{
Talent Management Based-Education: Indonesian Case
}

\author{
Lucia H Winingsih
}

\author{
Iskandar Agung
}

\author{
Agus Amin Sulistiono \\ Center for Research of Education and Culture, \\ Research and Development and Books Agency, MOEC, \\ Jln. Jend. Sudirman, Senayan, Building E-19 Fl, Central Jakarta, Indonesia
}

Doi: 10.36941/mjss-2020-0032

\section{Abstract}

This study aims to determine the effect variables on the implementation of talent management of based education (TMBE). The paper is part of the results study in 3 (three) cities in DKI Jakarta, Banten, West Java Province, Republic of Indonesia with a sample of three senior high schools each taken by purposive technique, especially good criteria and have teacher guidance and counseling status. From each school 20 high school teachers were randomly drawn to answer the questionnaire distributed to them. The questionnaire was previously validated and reliable using the product moment test criteria from Pearson and Cronbach Alpha with the help of the SPSS program version 24.0. Data is processed and analyzed using the Structural Equation Modeling (SEM) approach using the Lisrel 8.70 program. The study resulted that the provincial government policy variables (PDS), school conditions (SC), teaching activities (LT), teacher guidance and counseling (GC) functions, and parent participation (PP) had a direct positive effect on the TMBE, Cultural Values (CV), and National Education (NE) variables. The indirect effect of PDS, SC, LT, GC, $P P$ on TMBE is greater through CV and NE, then TMBE has a positive effect on Student Outcome (SO). It is recommended that TMBE implementation requires a holistic approach taking into account the variables and all the indicators studied. Ignoring one or more variables and trend indicators will influence the success or failure of talent-based education management and in turn will have an impact on student achievement (SO).

Keywords: talent management, teaching-learning, culture values, nationality education

\section{Introduction}

The criticisms that have been raised by various parties regarding the implementation of national education system in Indonesia tend to be stagnant and unchanged for decades. It tends to be conventional, mass, and not up to date with the rapid development of technology. In the current era of digital technology, many business activities have been disrupted, due to the emergence of businesses that rely on the use of digital technology. Overall, many new business activities replace conventional forms, whether small, medium, or high business. Trade in goods through retail, for example, almost replaced it with on-line spending.

The implication is that the development of digital technology will have an impact on the implementation of education, not only demands the ability of teachers to increase the use of digital 
technology in their learning, but also change the mindset of mass-oriented education to be more personal, learning in the classroom anywhere and at any time, teachers - for real-world machines and resources, tests and collaboration, and more (Christensen, Horn, and Johnson, 2008; Hand, 2008; Kasali, 2017, 2018). Learning is now required to produce students' competencies, talents, creativity, and critical thinking in solving real problems.

Therefore, in current and future education, it is needed the talent management basededucation. Modifying the opinions of Rampersad (2006), Lewis and Heckman (2006), talent-based education is a process of utilization through optimal planning and development of student talent. A number of schools have indeed given attention to the talents of students, especially through teacher guidance and counseling, but are still limited. The reason is that only a few schools have guidance and counseling teachers. Data for 2017 records 22,993 secondary schools (public and private) in Indonesia with more than 4 million students, there are only 10,225 teacher guidance and counseling, and only 418 with the appropriate educational background. Schools in Indonesia still lack of 92,572 teachers guidance and counseling (Dutanews, 2017). In the capital city of Jakarta there are 585 secondary schools with more than 200,00o students and only 529 guidance and counseling teachers (Kemdikbud Republik Indonesia, 2018). The teacher guidance and counseling ratio for high school students in DKI Jakarta is 1: 2645, which means that one teacher must deal with 2,645 students (Kompas, 2013).

On the student side, only a few are utilizing teacher guidance and counseling to consult about the future according to their talents. Students rarely consult because they may be embarrassed to be labeled by peers as problem students. Efforts to continue education are less planned and directed, but more speculative. Most high school graduates are more interested in pursuing education in courses that are considered to be fast working as civil servants, private employees, hospital workers, and so on, rather than jobs that require certain competencies (which may not require a bachelor's degree). Though based on talent can lead someone to continue his life and work in the future that is appropriate, happy, develops interests and self-satisfaction.

In changing the implementation of education based on personal talent, a thorough and thorough analysis is needed. Talent-based education is no longer a matter of teacher guidance and counseling, but needs to be managed by stakeholders, starting with the central, provincial, regional, and school governments. However, it is recognized that talent-based education management is influenced by various internal and external factors simultaneously, so that without including his analysis of these factors can lead to poor results. This is tantamount to implementing education in the old pattern of being unable to develop student competencies according to their interests and talents. Talent-based education must be able to produce students who are independent, competent, creative, critical thinking, collaborative, and problem-solving skills.

This study will examine the factors that are suspected to influence the implementation of talent-based education. It is recognized that there are complexities of internal and external factors that influence the application of talent-based education. Especially the external factors that need to be considered are the role of local government, the school environment, learning teaching, teacher guidance and counseling functions, student parent participation, cultural values, and nationality. All of these factors are exogenous variables that affect endogenous variables of talent management based education. In particular the focus of attention on the regional government in question is the provincial government as the manager of senior high school education (SMA / SMK) as determined by the Law of the Republic of Indonesia. 23/2014 concerning Regional Government.

\section{Literature Review}

\subsection{Local Government Policy (PDS)}

In government administration in Indonesia there is a hierarchy of the distribution of power and authority between the center, provinces and regions (districts / cities), as stipulated in Law No. 23 of 
2014 as amendments to Law No. 32 of 2004 concerning Regional Government. The regulation applies the principle of regional autonomy in the distribution of provincial and district / city government authorities by giving greater authority in managing all aspects of development, except for aspects of foreign policy, defense, security, justice, monetary and national fiscal, and religion (Law No 32/2014 Article 10).

Indonesia's autonomous principle gives the district / city government more control over the sector / aspect of development in its region, as opposed to the policies and sectors / aspects that the central government deals with. Provincial governments of a number of counties / cities also have greater authority to issue development policies and strategies in their region. Policies issued may be regional regulations, Governor / Mayor / Regents Decree, or in other forms related to the implementation of development activities in the region. An example is the ban on the use of plastic shopping bags by the government of the city of Bogor, West Java, so that super markets, malls, marts, and more are no longer available and consumers are being asked to bring their own. Another example is the use of odd-numbered four-wheel drive vehicles in the state capital of Jakarta's DKI province, which is expected to reduce congestion. The strategies implemented by the provincial government of Jakarta is trying to provide public transportation convenient and secure, so that users of private vehicles will switch to use it.

The Government of the Republic of Indonesia from 2019 - 2014 has issued policies and commitments to build high quality, competitive and highly flexible human resources (HR) in the face of global change. Along with that, the development of talent-based education is under special emphasis to produce competent, professional, integrity, high-performance and creative student output capabilities. It is clear that central policies require a breakdown of operational policies and strategies at the local and school level. Especially at the school level, talent-based education is not only the duty of teacher guidance and counseling (which is often ignored by parents and students), but is an integral part of school management. Therefore, the issuance of local government policies and strategies related to talent education will influence the implementation of education in schools. Various studies have shown the significant impact of local government policies and strategies on school education performance, including improving the quality of education, implementing compulsory education, infrastructure development and so on (Ratih, 2017; Suparni, not years; Montolalu, 2015; Haji et al., None year).

\subsection{School Condition (SC)}

Experts have come up with different ideas about school, each according to their point of view. Some gave the idea of the school as a system of social interaction as a whole organization of personal interactions related to organic relations (Atmodiwiro, 2000), some saw it as a building or institution for learning and a place to receive and teach (Daryanto, 1997), others saw it as an input system, process, and output (Usman, 2016). In this paper the concept of schools is primary and secondary educational institutions consisting of physical and non-physical elements, human and non-human (Agung, 2010). Physical and non-human elements of the school include school / office buildings, classrooms, classrooms, meeting rooms, gyms, health rooms, school libraries, laboratory practicum, curriculum, and so on. Non-physical and human elements include principals, principals, teachers, administrative staff, health workers, library staff, laboratory staff, extracurricular instructors, and many more. All these elements need to be managed well and synergistically and mutually support the implementation of education in schools.

Talent-based education implicitly requires the support of all the elements above to develop high-quality, competitive, and highly capable competencies to anticipate, respond to, and adapt to change. Efforts to manage all elements of the school must be aimed at producing outputs of students who master knowledge and technology that are based on the development of student talent. Student output competencies are built on students' talents in dealing with changes and the development of the environment, as well as a competitive labor market. Schools will have difficulty developing 
student talent when confronted with inadequate or incomplete supporting elements, both inside and outside their external environment. Some examples from Setiadi, Eko, and Suwahyo (2008), Nur (2015), Mulyani (2012), Widagdorini (2017), and Safitriyani (2018) studies show that there is a positive influence of infrastructure, school performance and teachers on the quality of learning outcomes. and developing student talent.

\subsection{Learning Teaching (LT)}

Teaching and learning activities of teachers with students is a series of events that affect students in such a way that it feels easy to interact with the environment (Gagne, 1985). Corey (2011) defines learning as a process in which a person's environment is deliberately managed to allow certain behaviors in certain situations or to respond to certain situations. There are many opinions expressed by educators, but it can be concluded that learning is a deliberate teacher-student interaction process. In the Law of the Republic of Indonesia 20/2003 About the National Education System learning is defined as the process of interacting students with educators and learning resources in the learning environment.

There are various techniques or ways of teaching between teacher and students. Critics that often arise in old learning patterns are teahers who focus too much on lecture techniques, the teacher explains and students listen passively, the teacher becomes a source of knowledge, student dependence, lack of creativity, and so on. The teacher should not be the center of learning, but student-centered. Students who are subject to learning, show active, creative, and collaborative looking and developing, not only mastering knowledge but also solving life problems. In that context, teachers need to understand individual characteristics, talents, and abilities of students, and then provide assistance, guidance, motivation, facilitation, and so on (Agung, 2010a, 2010b, 2014: Agung and Santosa, 2017a).

The latter shows that the teacher's role is not only in teaching activities, but also in paying attention and developing students' characteristics, talents, and abilities. Teachers need to create and direct the abilities and talents of their students, provide guidance, encourage active search for knowledge, self-development, creativity, and ultimately build competence and independence to overcome factual problems for themselves and the environment.

\subsection{Function of Guidance and Counseling (GC)}

One of the parties tasked with helping determine interests and talents and directing student selfdevelopment is the guidance and counseling teacher (GC). One function that can be done is giving advice to each student to develop their potential optimally (Hallen, 2002). Paimun (2005) calls it a development function to help students channel their talents, interests, abilities, aspirations or ideals. He also said the GC teacher could also function to help students correct mistakes, make adjustments in social interactions, and others.

In reality, it is still rare for students to utilize the functions of a GC teacher to develop their characteristics, interests, and talents. Even students still feel ashamed to meet and consult with GC teachers, for fear of being labeled as problem children. In continuing their education to university, for example, most high school graduates often choose their favorite fields of study, because they join friends, want to work fast, or are speculative, without regard to their true interests and talents. It is not yet known how large the number of students who continue their education really matches their characteristics, interests, and talents. Hurlock (1980) argues that the use of GC teachers not only serves to direct the development of talent interests, but also has a positive influence on the emotional and psychological development of students. Steinberg (2002), Wulandari et al, (2014), Rusgiarti, (2014), Talkah, (2015), and Rangkuti, (2018) suggested that the function of the GC teacher had a positive influence on self-development and directed the talents of students. 


\subsection{Parent's Participation}

In simple terms participation can be interpreted as the involvement of a person or group of people to strive for the success of an activity, so as to achieve the expected goals. Davis and Newstrom (2004) argue that participation is the mental and emotional involvement of a person to achieve goals and take responsibility in them. Participation is the mental and emotional involvement of someone who is motivated to contribute and achieve group goals. In the sense that student parent participation is one of the factors in supporting achievement of school goals and outcomes. Studies by Rogers et al (2009), Đurišić and Mila (2017), Akhmad et al (2017), Syamsudduha (2017) shows that school achievement is good, one of which is caused by the participation of parents in schools. Putri (2010), Mutodi and Ngirande (2014), Islami (2016), Muryati (2017), Persada et al (2017) show that active participation of parents in supporting activities in schools can improve the quality of learning. There are at least 4 (four) aspects of parental participation in the administration of education in schools namely: participation in school finance, participation in the provision of learning facilities, participation in renovating the school and classroom, participation in teacher teaching skills, and more. Of course, this participation should be avoided by too deep an involvement in school management and learning authority.

Parental involvement is also needed in the school's efforts to identify the characteristics and talents of the students, and then support its development, especially in terms of funding, facilities provision, and other school needs. Parents must understand that it aims to determine the interests and talents of students to be more focused plan for their future. But school effort is difficult to achieve without having a good GC teacher and instrument, such as sports activities, art activities (voice arts, dance, drama, drawing, chiseling, etc.), journalism, and so on. Parental participation is also related to the potential acquisition of experts that schools need to develop students' talents and interests. Allegedly concern parents of children's education in school will affect the success or failure of the implementation of talent management.

\subsection{Culture Values}

Pettigrew (1979), Sathe (1983), Davis (2004), and Haris and Ogbonna (in Sobirin, 2007) provide very similar understandings of the term culture as a system of open and collective meanings and use these beliefs and values as a guide. . behave in their social environment. From this understanding it can be concluded that culture is a value and belief that controls the behavior of its members. Cultural implicit is the mechanism of control of social systems in behavior. Schein (2014) argues, that culture has at least five dimensions of value orientation, namely: (1) concerning human relations with their environment; (2) human relations with truth; (3) human relationship with time; (4) human relations with activities; and (5) interpersonal relationships. The orientation of cultural values supported by a group of people from these five dimensions will have consequences for the actions taken (Lane \& Stefano in Agung, 2010a).

This paper is not intended to explain the cultural differences supported by these five dimensions, but rather to overcome the tendencies underlying student development, talent, and competence. The first dimension relates to the need to instill in students the value of mastery and trust in science and technology to cope with environmental change. The second dimension concerns the internalization of values to gather information and search for the truth of reality. The third dimension concerns the internalization of the value of working towards a better future through systematic planning. The fourth dimension is internalizing values to achieve better results through high motivation, creativity and innovation, hard work, discipline, and so on. The fifth dimension is to internalize the values of social relations that do not emphasize family ties in the workplace, but rather prioritize objective, fair motivation, achievement and competition to achieve a certain position. 


\subsection{Nationality Education}

Nationalism by Kohn (1965), Renan (1992), and Breully (2003) is defined as awareness and enthusiasm for the love of the state and nation which is shown through the attitudes and behaviors of individuals or communities. Bertrand (2004) argues that nationalism is fundamental in state organizations, and often crosses ethnic boundaries. In the context of Indonesia, the concept of nationalism with regard to national and state life is not only related to regional sovereignty as an archipelago, but also the integration of human diversity with their respective cultures (local and regional) and the development of national culture (symbols, attributes, rules, etc.) -other), under the umbrella of Pancasila, the 1945 Constitution, Bhinneka Tunggal Ika, the Unitary State of Indonesia.

Pancasila is the ideology of a nation and state consisting of: (1) One God, (2) Fair and Civilized Humanity, (3) Indonesian Unity, (4) Democracy, and (5) Social Justice (Indonesian Ministry of Information, 1987; Alfian , 1993; Decree of the People's Consultative Assembly of the Republic of Indonesia No. XVIII / MPR / 1998; Decree of the People's Consultative Assembly of the Republic of Indonesia No. I / MPR / 2003). The 1945 Constitution is the highest constitution and source of living law in the state and Republic of Indonesia which covers various aspects and functions as a guide for more operational rules in the form of laws, government regulations, regional regulations, and others. Bhinneka Tunggal Ika (BTI) is the motto of unity in the life of diversity in Indonesian society in terms of ethnicity, religion, race and intergroups that will be framed by awareness, attitudes, and behaviors that encourage unity and integration as a nation through an attitude of tolerance and mutual respect. Finally, the Unitary State of the Republic of Indonesia is a vision and commitment to support national life spread across thousands of islands, with many cultures, customs, languages and ways of life.

Talent-based education is also related to the development of students' character and nationalism. Carrying out education is not only about producing quality and competitive products through the mastery of science and technology, creativity, critical thinking, collaboration, and factual problem solving skills, but also national character and vision. Lickona (2009) argues that character education is an effort to instill values to create ways of thinking and behaving for individuals to live and work together in the family, in the community, and in the country (see also: Kusumah, 2013; Affan and Maksum, 2016 ). In Indonesia, since 2015 the minister of education and culture has issued regulation no. 23/2017 concerning Strengthening of Character Education (SCE), which is then strengthened by higher regulations in the form of Republic of Indonesia Presidential Regulation No. 87/2017. SCE is an effort to develop students' character to behave in accordance with the values, norms and rules possessed by the Indonesian people. There are five key values in the SCE program that are interrelated to form a value chain that needs to be developed, namely religion, nationalism, cooperation, integrity, and independence. Explicitly, one aspect of SCE is related to national awareness and attitude by showing loyalty, pride, and high respect for the nation and state.

\subsection{Talent Management Based Education (TMBE)}

Knowing someone's talent is important for future life, especially when confronted with intellectual intelligence is not the only benchmark of success. Gardner (2006) argues that there are 11 types of multiple intelligences in people, namely: verbal, linguistic, mathematical-logical, visual, musical, kinesthetic, interpersonal, intrapersonal, natural, existential, and spiritual. Persistence on the talent that one possesses will support the development of softskill, thus helping in competition and personal development in life. Education needs to pay more attention to the talents of the students and stimulate them to develop competencies that will be useful for later life.

But talent-based education is certainly influenced by the complexity of factors, as mentioned above. Even talent development efforts need to be aligned with responsive and adaptive attitudes towards the development of the global environment. Student competencies are not only required to develop creativity, critical thinking, collaboration, and problem solving skills, but also have English 
skills, computer literacy code reading, reading and mathematics literacy, the ability to develop and utilize digital technology, environmental adaptation, and global openness. . Implicit talent-based education seeks to build competence but also the ability to compete and utilize limited resources at home and abroad.

\subsection{Theoretical Framework}

Based on the above description, this study develop the theoretical framework of the study.

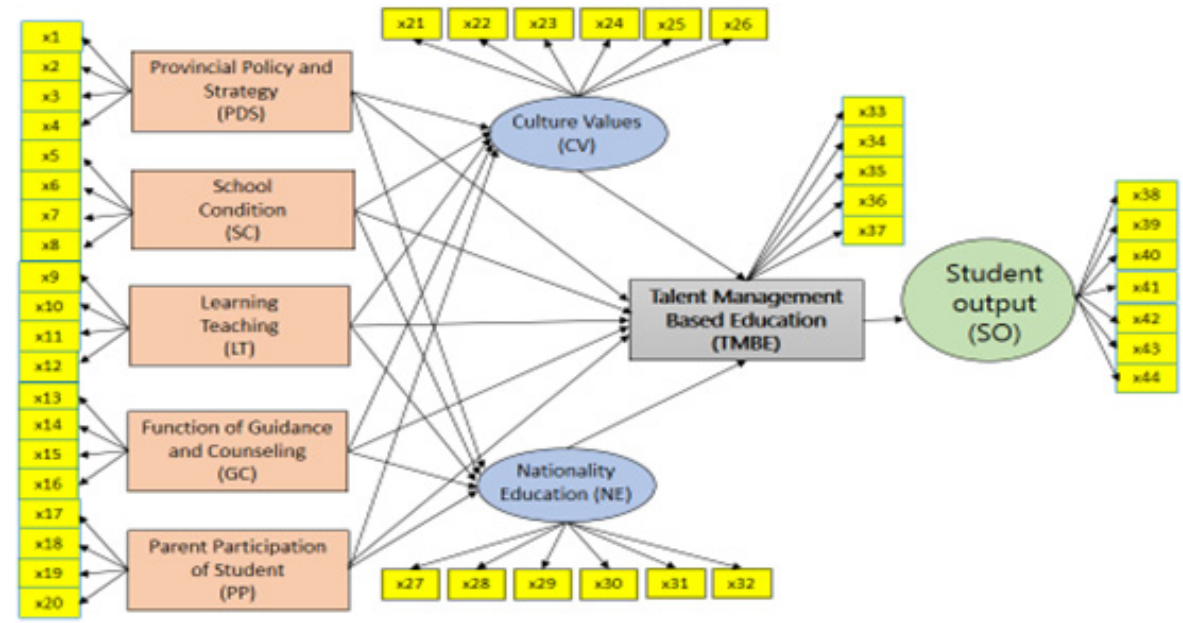

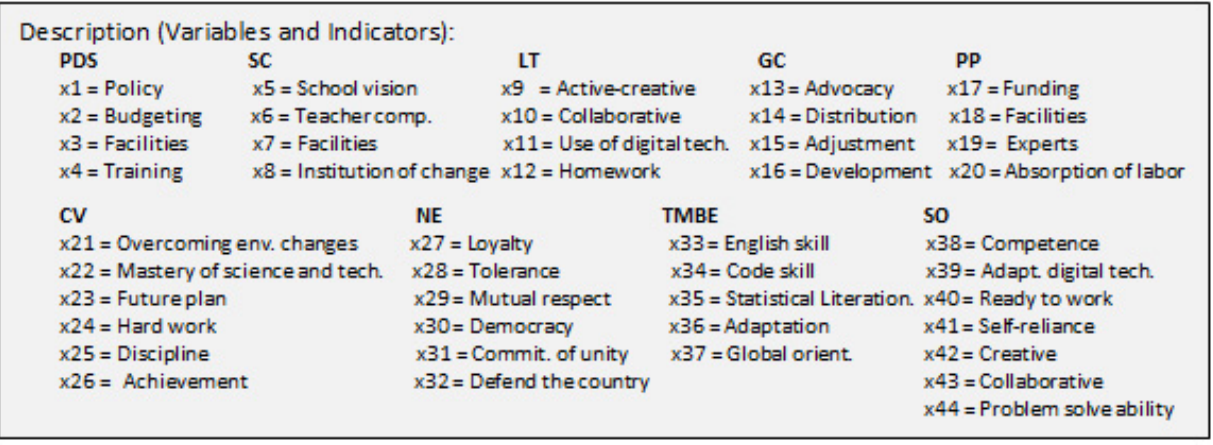

Diagram 1: Theoretical Framework of Talent Management Based Education (TMBE)

The hypothesis in the study are:

1. Variables of Provincial Government Policy and Strategy (PDS), School Condition (SC), Teaching Learning (LT), Counseling and Counseling (GC) Functions, Parent Participation (PP) have a direct impact on Talent Management Based Education (TMBE);

2. Variables of Provincial Government Policy and Strategy (PDS), School Condition (SC), Teaching Learning (LT), Counseling and Counseling (GC) Functions, Parental Participation (PP) have indirect effects through Cultural Values (CV) and National Education (NE) on Talent Management Based Education (TMBE);

3. Talent Management Based Education (TMBE) variable have a influence on Student Output (SO). 


\section{Methodology}

This paper is part of the 2019 field study results in 3 (three) cities, namely: Central Jakarta - DKI Jakarta Province, South Tangerang - Banten Province, Bogor - West Java Province. From each city randomly selected 8 (seven) high schools (4 public and 4 private) with the criteria of having guidance and counseling / psychologist status, then from each school 20 teachers were randomly selected as research samples. The total sample was 480 teachers. Regulations in Indonesia on regional autonomy give senior secondary management authority under the provincial government, while primary and secondary education management is under the authority of district / city governments.

This research focuses on senior high school level aimed at analyzing teacher perceptions about talent-based education, especially in identifying influencing factors. The main instrument used in data collection is the distribution of questionnaires to teachers. The items in the questionnaire were previously validated and verified using the product moment test criteria from Pearson and Cronbach Alpha with the help of the SPSS program version 24.o. In addition, information was obtained through interviews with the Principal and conducting focus group discussions (FGD) with participants from the Office of Education Officials, Principal, GC teachers, subject teachers, and parents of students. Data is processed and analyzed using the Structural Equation Modeling (SEM) approach using the Lisrel 8.70 program. Use of the SEM approach can done, because the sample meets the minimum requirements of 100 respondents (Kusnendi, 2009; Haryono and Wardoyo, 2013).

\section{Finding}

\subsection{Characteristic Respondent}

From the questionnaire distribution of 480 teachers only $402(83.75 \%)$ returned to the researchers, consisting of 258 people $(64.18 \%)$ men and 144 people $(35.82 \%)$ women. 16 people $(3.98 \%)$ had teachers with guidance and counseling education backgrounds, eight (1.99\%) had psychology education backgrounds, and the remaining 378 (95.03\%) were teachers in the fields of Chemistry, Physics, Mathematics, Economics, Geography, Sociology, Anthropology, and others. In terms of overall work experience, respondents gave answers that they had worked as teachers for more than 10 years. Almost all respondents were married with 2-5 children.

Almost all respondents answered that they were permanent teachers, either as civil servants or foundation workers. From the income side there are quite striking differences between public and Private teachers. Public teachers have an income level of between 15 million rupiah - 20 million rupiah, while private teachers range from 5 million rupiah - 10 million rupiah (note: 14,ooo rupiah $=\$$ 1 usd). This difference can be understood because public teacher respondents obtain income levels from basic salaries as government employees and teacher certification allowances, regional incentives, and teaching fees from schools, while private teachers only get income levels from foundations.

\subsection{Test the validity and reliability with CFA (Confirmatory Factor Analysis)}

Validity test is related to measuring variables so that they are said to be valid or not. Validity test is done by comparing the loading factor value with a minimum limit of 0.5 . If the loading factor value is than 0.5 then the indicator is valid. Reliability test shows the extent to which a measuring instrument that can provide relatively the same results if carried out measurements again on the same object. The reliability value is measured by Construct Reliability (CR) and Variance Extract (VE). It is said to be reliable if the value of $C R>0.70$ and $V E>0.50$. Following is a table 1 for testing the validity and reliability of the questionnaire. 
Table 1: Test Validity and Reliability of Indicators of Study Variable

\begin{tabular}{|c|c|c|c|c|c|c|c|c|c|c|c|}
\hline Var. & Ind. & SLF & CR & VE & Conclusion & Var. & Ind. & SLF & CR & VE & Conclusion \\
\hline \multirow{4}{*}{ PDS } & $\mathrm{x} 1$ & 0.91 & \multirow{4}{*}{0.9217} & \multirow{4}{*}{0.7505} & \multirow{4}{*}{$\begin{array}{c}\text { Valid } \\
\text { \& Reliable }\end{array}$} & \multirow{4}{*}{ CV } & $\mathrm{x} 23$ & 0.99 & \multirow{4}{*}{0.9572} & \multirow{4}{*}{0.7898} & \multirow{4}{*}{$\begin{array}{c}\text { Valid } \\
\text { \& Reliable }\end{array}$} \\
\hline & $\mathrm{x} 2$ & 0.98 & & & & & $\mathrm{x} 24$ & 0.87 & & & \\
\hline & $\mathrm{x} 3$ & 0.90 & & & & & $\mathrm{x} 25$ & 0.85 & & & \\
\hline & $\mathrm{X}_{4}$ & 0.64 & & & & & $\mathrm{x} 26$ & 0.78 & & & \\
\hline \multirow{4}{*}{ SC } & $\mathrm{x} 5$ & 0.91 & \multirow{4}{*}{0.8839} & \multirow{4}{*}{0.6588} & \multirow{4}{*}{$\begin{array}{c}\text { Valid } \\
\text { \& Reliable }\end{array}$} & \multirow{6}{*}{ NE } & $\mathrm{x} 27$ & 0.84 & \multirow{6}{*}{0.9731} & \multirow{6}{*}{0.8585} & \multirow{6}{*}{$\begin{array}{c}\text { Valid } \\
\text { \& Reliable }\end{array}$} \\
\hline & x6 & 0.98 & & & & & $\mathrm{x} 28$ & 1.00 & & & \\
\hline & $\mathrm{x} 7$ & 0.90 & & & & & $\mathrm{x} 29$ & 0.99 & & & \\
\hline & $\mathrm{x} 8$ & 0.64 & & & & & $\mathrm{X}_{30}$ & 0.98 & & & \\
\hline \multirow{4}{*}{ LT } & x9 & 0.94 & \multirow{4}{*}{0.9553} & \multirow{4}{*}{0.8428} & \multirow{4}{*}{$\begin{array}{c}\text { Valid } \\
\text { \& Reliable }\end{array}$} & & x31 & 0.90 & & & \\
\hline & $\mathrm{x} 10$ & 0.95 & & & & & $\mathrm{x} 32$ & 0.91 & & & \\
\hline & $\mathrm{x} 11$ & 0.95 & & & & \multirow{5}{*}{ TMBE } & $\mathrm{x} 33$ & 0.76 & \multirow{5}{*}{0.9517} & \multirow{5}{*}{0.7996} & \multirow{5}{*}{$\begin{array}{c}\text { Valid } \\
\text { \& Reliable }\end{array}$} \\
\hline & $\mathrm{x} 12$ & 0.83 & & & & & x34 & 0.70 & & & \\
\hline \multirow{4}{*}{ GC } & $\mathrm{x} 13$ & 0.76 & \multirow{4}{*}{0.9301} & \multirow{4}{*}{0.7728} & \multirow{4}{*}{$\begin{array}{c}\text { Valid } \\
\text { \& Reliable }\end{array}$} & & $\mathrm{x} 35$ & 0.94 & & & \\
\hline & $\mathrm{x} 14$ & 1.00 & & & & & $\times 36$ & 0.97 & & & \\
\hline & $\mathrm{x} 15$ & 1.00 & & & & & $\times 37$ & 0.90 & & & \\
\hline & $\mathrm{x} 16$ & 0.72 & & & & & $\times 38$ & 0.93 & & & \\
\hline \multirow{6}{*}{ PP } & $\mathrm{x17}$ & 0.93 & \multirow{4}{*}{0.9063} & \multirow{4}{*}{0.7093} & \multirow{4}{*}{$\begin{array}{c}\text { Valid } \\
\text { \& Reliable }\end{array}$} & & X39 & 0.90 & & & \\
\hline & $\mathrm{x} 18$ & 0.82 & & & & SO & $\mathrm{X}_{40}$ & 0.95 & & & \\
\hline & $\mathrm{x} 19$ & 0.88 & & & & & $\mathrm{x} 41$ & 0.87 & 0.9676 & 0.8103 & Valid \\
\hline & $\mathrm{x} 20$ & 0.72 & & & & & $\mathrm{x} 42$ & 0.87 & & & \& Reliable \\
\hline & $\mathrm{X}_{21}$ & 0.98 & & & & & $\mathrm{x} 43$ & 0.93 & & & \\
\hline & $\mathrm{X}_{22}$ & 0.99 & & & & & $\mathrm{X}_{44}$ & 0.94 & & & \\
\hline
\end{tabular}

Source: Study talent management based education: Indonesian case

The validity test results show that all indicators have a loading factor (SLF) value> 0.50. In the Provincial Policy and Strategy (PDS), School Condition (SC), Learning Teacher (LT), Function of Guidance and Counseling Teacher (GC), Parent's Participation (PP), Culture Values (CV), and Nationality Education (NE) variables, the results of the overall validity test show that all indicators have a loading factor value $(\mathrm{SLF})>0.50$. All indicators $\mathrm{x1}-\mathrm{x} 44$ represent valid criteria.

\subsection{Good of Fit (GOF) Model}

Structural model analysis in SEM starts with testing the suitability of the overall model based on the Goodness-of-Fit Index (GFI) statistical indicators of LISREL output (Hair et al, 2006). An overview of the critical values of the model matching test is presented in the summary of Table 2.

Table 2: Model Match Test

\begin{tabular}{|l|c|c|c|}
\hline Goodness-of-Fit & Cutt-off-Value & Results & Conclusion \\
\hline RMR (Root Mean Square Residual) & $\leq 0,05$ atau $\leq 0,1$ & 0.0230 & Good Fit \\
\hline RMSEA (Root Mean square Error of Approximation) & $\leq 0,08$ & 0.0167 & Good Fit \\
\hline GFI (Goodness of Fit) & $\geq 0,90$ & 0.98 & Good Fit \\
\hline AGFI (Adjusted Goodness of Fit Index) & $\geq 0,90$ & 0.96 & Good Fit \\
\hline CFI (Comparative Fit Index) & $\geq 0,90$ & 0.99 & Good Fit \\
\hline Normed Fit Index (NFI) & $\geq 0,90$ & 0.99 & Good Fit \\
\hline Non-Normed Fit Index (NNFI) & $\geq 0,90$ & 0.98 & Good Fit \\
\hline Incremental Fit Index (IFI) & $\geq 0,90$ & 0.99 & Good Fit \\
\hline Relative Fit Index (RFI) & $\geq 0,90$ & 0.98 & Good Fit \\
\hline
\end{tabular}

Source: Study talent management based education: Indonesian case

Table 2 shows all indicators showing that the SEM model is Fit or good. Data from the questionnaire was able to answer the theory that was built. 


\subsection{Structural Equation Results (SEM)}

Data analysis techniques in this study used Structural Equation Modeling (SEM) which was operated using the LISREL program version 8.7. The advantage of SEM application is its ability to confirm the dimensions of a concept or factor that is very commonly used in management as well as its ability to measure the influence of relationships that theoretically exist (Ferdinand, 2002). The structural model and loading factor values of the processed data are shown in diagrams 2 and 3.

\subsection{Hypothesis Test Results}

Hypothesis testing in this study was done by looking at the critical value (CR) at a $95 \%$ confidence level or $5 \%$ error, then the $C R$ value received was $>1.96$ (Hair, et.al, 2006). The table 3 explains that the 18 hypotheses proposed are acceptable because they obtain a T-value> 1.96.

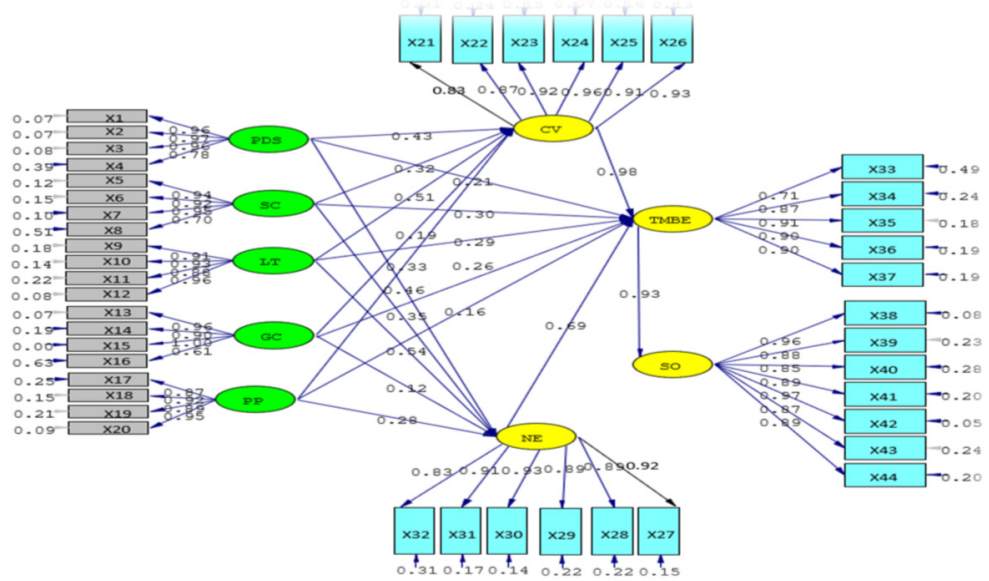

Diagram 2: Standardized Loading Factor

Source: Study talent management based education: Indonesian case

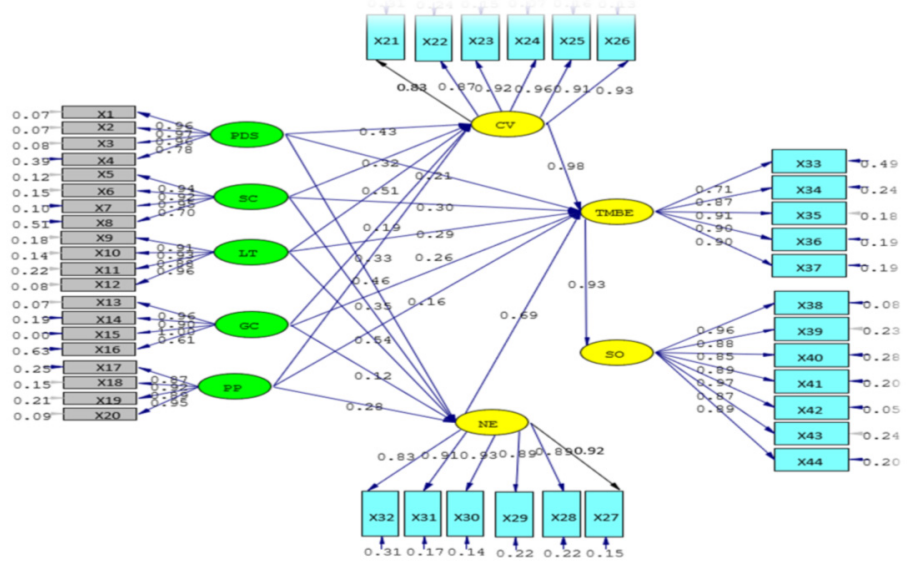

Diagram 3: T-Value

Source: Study talent management based education: Indonesian case 
Table 3: Hypothesis test results beetween study variables

\begin{tabular}{|l|c|c|c|l|c|c|c|}
\hline Hypothesis & Loading & T-Value & Conclusion & Hypothesis & Loading & T-Value & Conclusion \\
\hline PDS $\rightarrow$ CV & 0.43 & 31.25 & Accepted & GC $\rightarrow$ CV & 0.19 & 11.81 & Accepted \\
\hline PDS $\rightarrow$ NE & 0.46 & 27.85 & Accepted & GC $\rightarrow$ NE & 0.12 & 5.63 & Accepted \\
\hline PDS $\rightarrow$ TMBE & 0.21 & 3.81 & Accepted & GC $\rightarrow$ TMBE & 0.26 & 15.24 & Accepted \\
\hline SC $\rightarrow$ CV & 0.32 & 21.37 & Accepted & PP $\rightarrow$ CV & 0.33 & 25.80 & Accepted \\
\hline SC $\rightarrow$ NE & 0.35 & 19.96 & Accepted & PP $\rightarrow$ NE & 0.28 & 19.59 & Accepted \\
\hline SC $\rightarrow$ TMBE & 0.30 & 6.53 & Accepted & PP $\rightarrow$ TMBE & 0.16 & 4.32 & Accepted \\
\hline LT $\rightarrow$ CV & 0.51 & 47.05 & Accepted & CV $\rightarrow$ TMBE & 0.98 & 8.57 & Accepted \\
\hline LT $\rightarrow$ NE & 0.54 & 43.38 & Accepted & NE $\rightarrow$ TMBE & 0.69 & 17.33 & Accepted \\
\hline LT $\rightarrow$ TMBE & 0.29 & 5.42 & Accepted & TMBE $\rightarrow$ SO & 0.93 & 34.20 & Accepted \\
\hline
\end{tabular}

Source: Study talent management based education: Indonesian case

Table 3 shows that overall latent variables exogenous provincial government policies (strategies), school conditions (SC), learning teaching activities (LT), teacher guidance and counseling (GC) functioning, and parental participation (PP) have a direct positive effect. on latent endogenous variables Culture Value (CV), Nationality Education (NE), and Talent Management Based Education (TMBE). The indirect effect of PDS, SC, LT, GC, PP on TMBE was greater through CV and NE, which was 0.98 and o.69. TMBE was subsequently an exogenous latent variable that had a positive effect on the Student Outcome (SO) endogenous latent variable.

It seems that the exogenous latent variables of PDS, SC, LT, GC, PP have positive effects on TMBE, but they are better accompanied by efforts to teach and internalize cultural values to students about the importance of mastering science and technology in addressing environmental change issues and discovering truth, future planning, hard work, discipline, prioritizing better results or performance, and so on. The development of student talent education should be in line with efforts to instill national values and behaviors, among others: loyalty, tolerance, mutual respect, democracy, unity, and nationalism. All of these influential variables are situations that need attention in the implementation of talent-based education.

\subsection{Testing indicators in variables}

Based on the results of structural tests it is known the amount of contribution from the indicator values for each variable studied, as in table 4 .

Table 4: Indicator test results of the study variables

\begin{tabular}{|c|c|c|c|c|c|c|c|c|c|}
\hline Var. & Indicators & $\begin{array}{l}\text { Load. } \\
\text { Value }\end{array}$ & $\begin{array}{c}\text { Const. } \\
\text { Coef. }\end{array}$ & $\begin{array}{l}\text { Contri- } \\
\text { bution }\end{array}$ & Var. & Indicators & $\begin{array}{l}\text { Load. } \\
\text { Value }\end{array}$ & $\begin{array}{c}\text { Const. } \\
\text { Coef. }\end{array}$ & $\begin{array}{l}\text { Contri- } \\
\text { bution }\end{array}$ \\
\hline PDS & $\begin{array}{l}\text { x1 }=\text { Policy } \\
\text { x2 }=\text { Budgeting } \\
\text { x3 = Facilities } \\
\text { x4 = Training }\end{array}$ & $\begin{array}{l}0.07 \\
0.07 \\
0.08 \\
0.39\end{array}$ & $\begin{array}{l}0.96 \\
0.97 \\
0.96 \\
0.78\end{array}$ & $\begin{array}{l}0.0672 \\
0.0679 \\
0.0768 \\
0.3042 \\
\end{array}$ & PP & $\begin{array}{l}\mathrm{x} 17=\text { Funding } \\
\mathrm{x} 18=\text { Facilities } \\
\mathrm{x} 19=\text { Experts } \\
\mathrm{x} 20=\text { Labor }\end{array}$ & $\begin{array}{l}0.25 \\
0.15 \\
0.21 \\
0.09\end{array}$ & $\begin{array}{l}0.87 \\
0.92 \\
0.89 \\
0.95\end{array}$ & $\begin{array}{l}0.2175 \\
0.1380 \\
0.1869 \\
0.0855\end{array}$ \\
\hline SC & $\begin{array}{l}\mathrm{x} 5=\text { Vision } \\
\mathrm{x} 6=\text { Teacher comp } \\
\mathrm{x} 7=\text { Facilities } \\
\mathrm{x} 8=\text { Institution of change }\end{array}$ & $\begin{array}{l}0.12 \\
0.15 \\
0.10 \\
0.51\end{array}$ & $\begin{array}{l}0.94 \\
0.92 \\
0.95 \\
0.70\end{array}$ & $\begin{array}{l}0.1128 \\
0.1380 \\
0.0950 \\
0.3570\end{array}$ & CV & $\begin{array}{l}\text { x21 = Env.changes } \\
\text { X22 = Sc \& Tech } \\
\text { x23 = Future plan } \\
\text { x24 = Hard work } \\
\text { x25 = Discipline } \\
\text { x26 = Achievement }\end{array}$ & $\begin{array}{l}0.31 \\
0.24 \\
0.15 \\
0.07 \\
0.16 \\
0.13 \\
\end{array}$ & $\begin{array}{l}0.83 \\
0.87 \\
0.92 \\
0.96 \\
0.91 \\
0.93 \\
\end{array}$ & $\begin{array}{l}0.2573 \\
0.2088 \\
0.1380 \\
0.0672 \\
0.1456 \\
0.1209 \\
\end{array}$ \\
\hline LT & $\begin{array}{l}\text { x9 }=\text { Active-Creative } \\
\text { x10 = Collaborative } \\
\text { x11 = Digital tech } \\
\text { x12 }=\text { Homework }\end{array}$ & $\begin{array}{l}0.18 \\
0.14 \\
0.22 \\
0.08\end{array}$ & $\begin{array}{l}0.91 \\
0.93 \\
0.88 \\
0.96\end{array}$ & $\begin{array}{l}0.1638 \\
0.1302 \\
0.1936 \\
0.0768\end{array}$ & NE & $\begin{array}{l}\text { x27 }=\text { Loyalty } \\
\text { x28 }=\text { Tolerance } \\
\text { x29 }=\text { Mutual resp. } \\
\text { x30 = Democracy } \\
\text { x31 = Unity } \\
\text { x32 = Defend }\end{array}$ & $\begin{array}{l}0.31 \\
0.17 \\
0.14 \\
0.22 \\
0.22 \\
0.15 \\
\end{array}$ & $\begin{array}{l}0.83 \\
0.91 \\
0.93 \\
0.89 \\
0.89 \\
0.92 \\
\end{array}$ & $\begin{array}{l}0.2573 \\
0.1547 \\
0.1302 \\
0.1958 \\
0.1958 \\
0.1380 \\
\end{array}$ \\
\hline
\end{tabular}




\begin{tabular}{|c|c|c|c|c|c|c|c|c|c|}
\hline Var. & Indicators & $\begin{array}{l}\text { Load. } \\
\text { Value }\end{array}$ & $\begin{array}{l}\text { Const. } \\
\text { Coef. }\end{array}$ & $\begin{array}{l}\text { Contri- } \\
\text { bution }\end{array}$ & Var. & Indicators & $\begin{array}{l}\text { Load. } \\
\text { Value }\end{array}$ & $\begin{array}{c}\text { Const. } \\
\text { Coef. }\end{array}$ & $\begin{array}{l}\text { Contri- } \\
\text { bution }\end{array}$ \\
\hline GC & $\begin{array}{l}\mathrm{x13}=\text { Advocacy } \\
\mathrm{x14}=\text { Distribution } \\
\mathrm{x15}=\text { Adjustment } \\
\mathrm{x16}=\text { Development }\end{array}$ & $\begin{array}{l}0.07 \\
0.19 \\
0.00 \\
0.63\end{array}$ & $\begin{array}{l}0.96 \\
0.90 \\
1.00 \\
0.61\end{array}$ & $\begin{array}{c}0.0672 \\
0.1710 \\
0.0000 \\
0.3843\end{array}$ & TMBE & $\begin{array}{l}\text { X33 = Engl. skill } \\
\text { x34 = Code skill } \\
\text { x35 = Stat. Lit. } \\
\text { x36 = Adaptation } \\
\text { x37 = Glob. orient. }\end{array}$ & $\begin{array}{l}0.49 \\
0.24 \\
0.18 \\
0.19 \\
0.19\end{array}$ & $\begin{array}{l}0.71 \\
0.87 \\
0.91 \\
0.90 \\
0.90\end{array}$ & $\begin{array}{l}0.3479 \\
0.2088 \\
0.1638 \\
0.1710 \\
0.1710\end{array}$ \\
\hline
\end{tabular}

Source: Study talent management based education: Indonesian case

\section{Discussion}

The hypothesis test results indicate that the variables used in this study have a positive impact on the implementation of talent management-based education (TMBE). TMBE explicitly needs to be approached holistically with emphasis on school conditions (SC), teaching learning (LT), and teacher guidance and counseling (GC) functions. This approach also involves the importance of introducing, internalizing, and understanding cultural $(\mathrm{CV})$ and national $(\mathrm{NE})$ values that show greater coefficient values in influencing TMBE. Ignoring one or more of these variables will affect the success or failure of a talent management-based education development, and in turn will impact student achievement (SO).

A holistic approach that takes into account all of the elements / aspects is also based on the indicators of each study variable. The calculation of the contribution of values provided by a particular indicator is only meant to indicate the emphasis that must be given to each of the variables. As shown in table 4 , the training indicator $\left(\mathrm{x}_{4}\right)$ provided the highest value of the provincial governmental policy variable (PDS) of 0.3042 , followed by facility support ( $x_{3}$ ) of 0.768 , budgeting (x2) of 0.679 , and regional regulations (x1) of 0.672 . This means that schools need more training on the implementation of talent-based education along with the necessary budget support and facilities from the provincial government.

In the variable school condition (SC) indicators that contributed the highest value were the institution of change $(\mathrm{x} 8)$ of 0.3570 , followed by teacher competence $(\mathrm{x} 6)$ of 0.1380 , school vision $\left(\mathrm{x}_{5}\right)$ of 0.1128 , and school of learning (x7) of 0.0950 . This shows that schools as institutions of change that educate students (including efforts to develop student characteristics, interests, and talents) are perceived to be a key place for respondents. In line with their role as change institutions, respondents also perceived the need to be supported by competent teachers, school visions, and learning facilities. Without such support (and other aspects of the school) synergistically, the school as a institution of change to equip science and technology and prepare for a better future for students would not have been possible.

Development and utilization of digital technology (xil) by teachers as respondents considered the indicators to contribute the highest to the Learning Teaching (LT) variable of 0.1936 , followed by the active and creative attitude (x9) of 0.1638 , collaborative (x10) is 0.1302 , and homework (x12) is 0.0768 . It can be argued that respondents place a strong emphasis on teachers' ability to develop and leverage digital technology in current and future learning, whether it is facilitating teaching, teacher and student communication, sources of references, and so on. On that basis, learning is required to be active, creative, and collaborative among teachers of the same subject. Instead of providing homework as teachers often incorporate into their learning patterns, it is less important.

In the teacher guidance and counseling (GC) variables, the talent development indicator (x16) contributed the highest value of 0.3843 , followed by the distribution of study programs corresponding to the student talent (x14) of 0.1710 , and advocacy (x13) of 0.0672 . This means that the development function and efforts to direct the future and the selection of student-centered study programs are considered to be prioritized by school and teacher guidance and counseling.

The funding indicator $(\mathrm{xi7})$ contributed the highest value to the variable Parent Participation (PP) of 0.2125 , followed by support to find experts (x19) to improve the ability of staff / employees 
(including teachers) of 0.1869 , provision of facilities (x18) amounted to 0.1380 , and the absorption of graduates in employment (x20) amounted to 0.0855. Talent-based education was assessed by respondents as requiring funding from students' parents, not only to invite relevant and competent experts, but also to procure instruments, staff fees, and others. On the other hand respondents also rated the development of student talent as required by parents in providing adequate facilities, especially to facilitate activities in schools, such as the provision of instruments for dance, music, sports, journalism, and so on. The participation of parents in the absorption of graduates as workers is not prioritized by respondents, perhaps this is because the object of the teacher being studied is from high school so it is more likely that graduates will continue their education to university, not to work.

Talent-based student education needs to be supported by ownership of conducive cultural values. Table 4 shows a set of cultural values as indicators that contribute to the cultural value variable $(\mathrm{CV})$ in influencing the TMBE variable. Indicators of coping with environmental change (x21) contributed the highest value to the CV variable of 0.2573 , followed by confidence in science and technology to cope with environmental changes and finding truth (x22) of 0.2088 , the importance of looking at the future with careful planning ( x23) of 0.1380, discipline (x25) of 0.1456, achievement orientation (x26) of 0.1209, and hard work (x24) of 0.0672. Although statistical processing shows differences in the number of indicators of cultural values, in principle it needs to be internalized to students to make it a guide for behavior in living life now and in the future.

Talent-based education for students was also considered by the respondent to be accompanied by national education, especially internalization of the values of loyalty, tolerance, mutual respect, democracy, unity, and national defense. Table 4 shows the loyalty value is an indicator that gives the highest contribution to the nationality education variable $\left(\mathrm{x}_{27}\right)$ of 0.2573 , followed by the value of democracy and unity (x30, x31) of 0.1958 , tolerance (x28) of 0.1547 , defending the country $\left(x_{32}\right)$ of 0.1380 , and mutual respect (x29) of 0.1302. Although there are differences in the contribution of indicators in the NE variable, in principle the values contained need to be internalized thoroughly so that students can use as guidelines for behavior in national life.

All of the above has influenced the implementation of TMBE in schools. In the face of advancing times, especially digital technology, talent education also needs to build students to have English language skills, code literacy, statistical literacy, adaptation to environmental change, and global orientation (see: Agung, 2017b). English language skills are needed to facilitate and facilitate communication in the international community and others. Table 4 shows the ability to speak English (x33) as an indicator that contributed the highest value to the TMBE variable of 0.3479 , meaning that respondents were perceived as the main priority that students needed to master. The second indicator that contributes the highest value is code literacy (x34), i.e. the ability to read computer language code by 0.2088 , followed by the ability to adapt to changing environments and globally oriented (x36, x37) by 0.1710 , and finally statistical literacy (x35) of 0.1638 .

\section{Conclusion}

This study results that the exogenous latent variables of provincial government policies (PDS), school conditions (SC), teaching activities (LT), teacher guidance and counseling (GC) functions, and parental participation (PP) have a direct positive effect on endogenous latent variables Talent Management Based Education (TMBE), Cultural Values (CV), and National Education (NE). The indirect effect of PDS, SC, LT, GC, PP on TMBE is greater through CV and NE, while TMBE is an exogenous latent variable that has a positive effect on the endogenous latent variable Student Outcome (SO).

It seems that exogenous latent variables from PDS, SC, LT, GC, PP have a positive effect on TMBE, but they are better accompanied by efforts to teach and internalize cultural values to students about the importance of mastering science and technology in addressing environmental changes, beliefs towards science and technology in overcoming environmental problems and finding truth, 
future planning, hard work, discipline, prioritizing results or better performance, and so on. In addition, the education of student talent must be in line with efforts to instill national values and behavior, including: loyalty, tolerance, mutual respect, democracy, unity, and nationalism.

It is recommended that the implementation of TMBE requires a holistic approach by taking into account the variables and all the indicators studied. Ignoring one or more of the variables and indicators that will affect the success or failure of talent-based education management and in turn will have an impact on student achievement (SO). Even so in the implementation of TMBE can be given emphasis on indicators that contribute the highest value in each variable studied.

\section{References}

Admodiwiro, S. (2000). Education Management, Jakarta: Publisher Ardadizya.

Affan, M, H., Maksum, H. 2016. Rebuilding the Indonesian Nationalism's Attitude in Counteracting Foreign Culture in the Era of Globalization, Basic Enchantment Journal, Vol. 3 (4), 65 - 72.

Agung, I. (2010a). The Impact of Organizational Culture, Leadership, and Job Satisfaction on the Performance of Top School Teachers in Jakarta DKI Provinces, dissertation, Jakarta State University.

Agung, I. (2014). Continuing Professional Development (CPD) School Paradigm Change. Eduacational Journal, Jakarta: Center of Center Policy, MOEC Republic Indonesia. https://www.scribd. com/document/358823065/CPD-Dan-Perubahan-Paradigma-Sekolah

Agung, I., Santosa, A. (2017a). Continuing Development Professional Teacher, Jakarta: Bee Media Publishing.

Agung, I. (2017b). Teacher Competencies and Professionals: 21st Century Perspective, Professor Oration Paper, Indonesian Institute of Sciences - MOEC Republic of Indonesia.

Akhmad, N. A., Hassan S.A., Ahmad A.R., Chua L.N., Othman N. (2017). parental involvement in learning environment, social interaction, communication, and support towards children excellence at school, Journal of Sustainable Development Eduaction and Research, Vol. 1 (1), 83 - 9o. http://dx.doi.org/10.17509/jsder.vii1.6247

Alfian, O (1993). Pancasila as Ideology, Surabaya: Karya Anda.

Bertrand J. (2004). Nationalism and Ethnic Conflict in Indonesia, New York: Cambridge University Press.

Breuilly, J. ed. (2013). The Oxford Handbook of the History of Nationalism, Oxford University Press.

Christensen, C. M., Horn, M. B., Curtis W. (2008). Disrupting Class: How Disruptive Innovation Will Change the Way the World Learns. New York: McGraw-Hill.

Corey, G. (2011). Theory and Practice of Counseling and Psychotherapy, Jakarta: Publisher Refika Aditama.

Daryanto. (1997). Educational Evaluation, Jakarta: Rineka Cipta Publisher.

Davis, K., Newstrom, J. W. (2004). Organizational Behavior, McGraw-Hill.

Davis, S. M. (2004). Managing Corporate Culture, Cambridge Mass: Balinger Publishing Company.

Đurišić, M., Mila, B., (2017). Parental Involvement as a Important Factor for Successful Education, C.E.P.S Journal, Vol. 7 (3), 137 - 153. https://files.eric.ed.gov/fulltext/ EJ1156936.pdf

Dutanews, 2017. The shortage of teacher (http://www.dutanews.net / 2017/08/o7 / prof-mungin-indonesiashortage-teacher-bk/)

Ferdinand, A. (2006). Structural Equation Modeling in Management Research: Application of Complex Models in Research for Master Thesis and Doctoral Dissertations. Semarang: Diponegoro University Publisher Agency.

Gagne, R.M (1985). The Conditions of Learning and Theory of Instruction, Publisher: Wadsworth Pub Co.

Gardner, H. (2006). Multiple Intelegence, New York: Basic Books.

Haji, E., Kiyai, B., Pombengi, J. D. (no year). The Role of the Local Government in Establishing the Development of Educational Infrastructure (A Study in Higher Secondary School (SMA/MA). https://media.neliti.com/media/publications/1414-id-peran-pemerintah-daerah-dalam-mewujud-kanpembangunan-infrastruktur-pendidikan-su.pdf

Hallen A. (2002). Guidance and Counseling, Jakarta: Ciputat Press.

Hand, D. B. (2008). Reviewing Disrupting Class: How Disruptive Innovation Will Change the Way the World Learns. Journal of the Scholarship of Teaching and Learning for Christians in Higher Education, 3(1), 14-17. http://digitalshowcase.oru.edu/ sotl ched/vol3/iss1/6

Hair Jr. J. F., William C., Black Ba. J., Babin R. E. A. (2010). Multivariate Data Analysis, United States: Pearson.

Haryono. S., Wardoyo, P. (2017). Structural Equation Modeling (SEM) for Management Research with AMOS 18.oo, Jakarta: Luxima Metro Media.

Hurlock, E. B. (2017). Developmental psychology, Erlangga Publisher.

http://www.dutanews.net/2017/o8/o7/prof-mungin-indonesia-kekurangan-guru-bk/

https://edukasi.kompas.com/read/2013/o1/23/11190821/Sekolah.Kekurangan.92.572.Guru. Konseling. 
Islami, L. N. (2016). Relationship of Parent Participation with Social Studies Learning Outcomes of Class V Students of SDN Cluster Arief Rahman Hakim Kendal District Kendal Regency, Education Science Semarang State University.

Kasali, R. (2017). Disruption, Jakarta: Penerbit Gramedia.

Kasali, R. (2018). Self Disruption, Jakarta: Penerbit Mizan.

Kohn, H. (1965). Nationalism Its Meaning and History, Paperback, Anvil Books.

Kompas. (2013). Kekurangan Guru Bimbingan dan Konseling. https: // education. Kompas.com/read/2013/ 01/23/11190821 / School. Weakness.92.572. Teacher. Counseling).

Kusnendi, (2009). Structural Equation Models, Bandung: Alfabeta.

Kusumah, S. D. (2013). Study of the Character Education Model at the Dinniyah Puteri Modern Islamic Boarding School in the Dinniyah Puteri Padang Panjang College West Sumatra, Patanjala Journal, Vol. 5 (1), 54 - 68.

Law of the Republic of Indonesia 20/2003 About Nacional Education System.

Law of the Republic of Indonesia 23/2014 About Local Government.

Lickona, T (2009). Educating for Character, New York: Penguin Random House Publishing.

Ministry of Information of the Republic of Indonesia. (1987). Pancasila Ideology and State Foundation of the Republic of Indonesia, Jakarta.

MOEC Republic of Indonesia. (2018). Educational Reference Data. Jakarta.

Montolalu, (2015). The Government's Role in Creating Mandatory Education in the Matuari District of Bitung City, thesis, Faculty of Social Sciences and Politics of Sam Ratulangi University. https://media.neliti.com/media/publications/1132-ID-peranan-pemerintah-dalam-mewujudkan-pendidikanwajib-belajar-di-kecamatan-matuar.pdf

Ministry of Education and Culture of the Republic of Indonesia. 2017. Strengthening of Character Education: Concepts and Guidelines, Jakarta.

Mulyani, A. (2012). The influence of Principal anf Teacher Performance on Learning Quality in Purwakarta District, Jurnal Adminisistrasi Pendidikan Vol. XIV (1), 86 - 92. https://media.neliti.com/media/ publications/77315-ID-pengaruh-kinerja-kepala-sekolah-dan-kine.pdf

Muryati (2017). Empowering Parents in Improving the Quality of Learning at SDN Sabranglor No. 78 Surakarta, Postgraduate School of Muhammadiyah University, Surakarta.

Mutodi, P., Ngirande, H. (2014). The Impact of Parental Involvement on Student Performance: A Case Study of South African Secondary School. Mediterranian Journal on Social Sciences, Vol. 5 (8). 279 - 289. DOI: 10.5901/mjss.2014.v5n8p279

Nur, J. (2015). Influence of Learning Methods on the Interests of Vocational Students in the Junior High School 4 Tenggarong, Journal of Cemerlang, Vol. III (1), 1 - 8. file:///C:/Users/ TOSHIBA/Downloads/ 46-132-1-PB.pdf

Paimun (2005). Guidance and Counseling, Jakarta, UIN Syarif Hidayatullah.

Persada, N. M., Pramono. S. E., Murwatiningsih. (2017). Parent Involvement in Children's Education at Al Farabi Islamic Science Elementary School, Cirebon, Educational Management, Vol. 6 (2). $100-108$. https://journal.unnes.ac.id/sju/index.php/eduman.

Pettigrew, A. (1979). On Studying Organizational Culture, Administrative Science Quarterly, 570 - 581.

Presidential Rule Republic of Indonesia No. 87/2017 About Character Education.

Putri, P. (2010). Parent Participation in Improving Academic Achievement of Class VIII Students in Tsanawiyah Hasanah Madrasah Pekanbaru, Sultan Syarif Kasim Riau State Islamic University, Pekanbaru.

Rampersad, H. K. (2006). Personal Balance Scorecard: The Way to Individual Happiness, Personal Integrity and Organization Effectiveness. New York: McGraw-Hill.

Rangkuti, A. R. (2018). Case Study of Learning Difficulties and the Role of Counseling Guidance in Madrasah Tsanawiyah Al-Washliyah Tembung Students, Islamic University of North Sumatra: Counseling Guidance Study Program.

Ratih, L. P. (2017). Role of Local Government in Quality Improvement of Yogyakarta State University. https://www.kompasiana.com/linapsp/59e2f7f3of6 14511315645 d2 /peran-pemerintah-daerah-dalampeningkatan-mutu-sekolah-dasar?page=all.

Renan, E. (1992). "What is a Nation?, Text of a conference delivered at the Sorbonne on March 11th, 1882, in Ernest Renan, Qu'est-ce qu'une nation ?, Paris, Presses-Pocket. (translated by Ethan Rundell)

Robert, E. Lewis, R. E., Heckman, R. J. (2006). Talent management: A critical review, Human Resource Management Review, Vol.16, 139-154. doi:10.1016/j.hrmr.2006.03.001

Rusgiarti. (2014). Case Study of Difficulties in Learning Biology Subjects in Class VII of Pontianak National Middle School, Educational Journal, Vol. 1 (1), 102 - 110. 
Safitriyani, A. (2018). Effect of Infrastructure and Learning Motivation on the Study Results of IIS SMAN Class X Student 11 City of Jambi, Thesis, Faculty of Teaching and Educational Sciences of Jambi University. http://repository.unja.ac.id/5419/1/ARTIKEL\%2o REPOSI TORY.pdf

Sathe, V. (1983). Implications of Corporate Culture: A Manager Guide's to Action, Organizational Dynamics, 4 23.

Schein, E. H. (2014). Organizational Culture and Leaderhip, San Fransico: Jossey-Bass publishers.

Setiadi, Eko, B., Suwahyo. (2008). The Effect of Study Facilities and Infrastructures Toward Study Result In Measuring Tools Subject, Jurnal Pendidikan Teknik Mesin, Vol. 8 (2), 83 - 86. https://journal.unnes.ac.id/nju/index.php/JPTM/article/view/1197/1154

Sobirin, A. (2007). Budaya Organisasi: Pengertian, Makna dan Aplikasinya dalam Kehidupan Organisasi, Yogyakarta.

Steinberg, L. (2014). Age of Opportunity: Lessons of from the New Science of Adolescence. New York: MGCraw Hill Companies, Inc.

Subroto, T., Sholihah, W. (2018). Barriers to Learning Analysis on Trigonometry Material in Students' Mathematical Understanding Ability, 109 - 120. https://www.researchgate.net/publication/ 327958836Analisis_Hambatan_Belajar_Pada_Materi_Trigonometri Dalam_Kemampuan_Pemahaman_Matematis_Siswa.

Suparni. (no year). The Role of the Central Government as Organizer of National Education and the Regulator as Regulator, Supervisor and Executor of Education in Efforts to Improve Primary School Quality, SDN Keputran 2 Yogyakarta. https://www.academia.edu/34887736/Peran Pemerintah_Pusat_Sebagai _Penyelenggara_Pendidikan_NasionalDan_Pemda_Sebagai_RegulatorPengawas_Serta_Pelaksana_Pendidik an_Dalam_Upaya_Meningkatan_Mutu_Sekolah_Dasar

Susanto, A. (2016). Learning Theory and Learning in Primary Schools, Kencana Publishers.

Syafaruddin, Syarqawi, A., Siahaan, D. N. A. (2019). Guidance and Counseling Basics: Study Concepts, Theories and Practices, Perdana Publishing.

Syamsudduha, St. (2017). Parent Participation in Child Education in Schools at Al-Fityan SDIT, Gowa Regency, Journal al-Kalam, Vol. IX (2), $141-158$.

Talkah, W. (2015). Guidance Service Level of Learning Difficulties of Students of Udanawu 1 State Vocational School in Blitar District Affects Student Learning Motivation, Journal of Professional Education, Vol. 4 (2), $87-95$.

The Decree of the People's Consultative Assembly of the Republic of Indonesia No. XVIII / MPR / 1998 concerning the Ideology of Pancasila.

The Decree of the People's Consultative Assembly of the Republic of Indonesia No. I / MPR / 2003 concerning Introduction, appreciation and practice of Pancasila.

Widagdorini, H. (2017). Teacher Performance in Enhancing Education Quality Through Curriculum 2013 at Timpik Elementary School o1 Year 2017, Thesis, Faculty of Teaching and Education Sciences. http://eprints.ums.ac.id/53722/19/ NASKAH\%2o PUBLIKASI.pdf

Wulandari, M., Djaya, S., Suharso, P. (2014). Accounting Learning Difficulties Analysis in Adjusting Journal Materials (Case Study of Social Sciences Class XI Students in Pakusari 1 Public High School Academic Year 2013-2014), UNEJ Educational Journal, Vol. I (2), 23-27. 